\title{
POTENCJALNE ZASTOSOWANIA CROWDSOURCINGU W PRAWOTWÓRCZYCH PROCESACH DECYZYJNYCH
}

\section{Abstract \\ Potential applications of crowdsourcing in legislative decision-making processes}

Crowdsourcing can be treated as one of the new methods of citizen participation in public decisions, including the creation of legal regulations. The author, using the interdisciplinary approach and decision analysis, describes the process of changing the traditional paradigm of exercising public authority and points to the potential applications of the so-called 'wisdom of the crowd' at particular stages of the legislative decision-making process. One can distinguish here: diagnostic crowdsourcing (ex ante) and evaluation (ex post). The author also analyzes potential applications of crowdsourcing techniques in relation to selected dimensions included in the Legislator Decision-making Model (instrumental, axiological, social normative system, social conflict and discursive). Crowdsourcing implemented in an appropriate manner by law-making institutions can play a complementary role in moderating social dialogue and seeking innovative applications of legal means to solve social problems, strengthening the authority of law and contributing to the improvement of the quality of regulations.

Keywords: crowdsourcing, collective intelligence, law-making policy, legislation, politics of law

\section{Streszczenie}

Crowdsourcing może być traktowany jako jedna z nowych metod partycypacji obywateli w decyzjach publicznych, w tym również i w sferze tworzenia regulacji prawnych. Autor, wykorzystując podejście interdyscyplinarne i analizę decyzyjną, opisuje proces zmiany tradycyjnego paradygmatu sprawowania władzy publicznej i wskazuje na potencjalne zastosowania tzw. mądrości tłumu na poszczególnych etapach prawotwórczego procesu decyzyjnego. Wyróżnić tu można: crowdsourcing diagnostyczny (ex ante) i ewaluacyjny (ex post). Przedmiotem rozważań są także potencjalne zastosowania tzw. mądrości tłumu w odniesieniu do wybranych wymiarów ujętych w Modelu Pola Decyzyjnego Ustawodawcy (wymiar instrumentalny, aksjologiczny, 
społecznego systemu normatywnego, konfliktu społecznego oraz dyskursywny). Realizowane w odpowiedni sposób przez instytucje prawotwórcze projekty crowdsourcingowe mogą odgrywać uzupełniającą rolę w moderowaniu dialogu społecznego i poszukiwaniu innowacyjnych zastosowań środków prawnych do rozwiązywania problemów społecznych, wzmacniając przy tym autorytet prawa i przyczyniając się do poprawy jakości regulacji.

Słowa kluczowe: crowdsourcing, inteligencja zbiorowa, prawo, legislacja, polityka prawa

\section{Wstęp}

Celem niniejszego opracowania jest wskazanie potencjalnych zastosowań crowdsourcingu w prawotwórczych procesach decyzyjnych zachodzących we współczesnych demokratycznych systemach społeczno-politycznych. Rozważania dotyczą naukowej polityki prawa, czyli dziedziny wiedzy, której głównym zadaniem jest ,dostarczenie szeroko rozumianemu suwerenowi narzędzia do osiągania założonych celów z wykorzystaniem norm prawnych" [Zirk-Sadowski, 2013: 191]. Polityka tworzenia prawa (polityka legislacyjna) obejmuje zaś „,założenia i zamiary podmiotów prawodawczych (biorących udział w procesie tworzenia prawa) zmierzających poprzez tworzenie norm prawnych do realizacji określonych celów polityczno-społecznych" [Leszczyński, 2003: 17]. Niewątpliwie skuteczność prawa w społeczeństwie informacyjnym uzależniona jest $\mathrm{w}$ dużej mierze od otwarcia się instytucji tworzących prawo na różnorodne formy dialogu $\mathrm{z}$ adresatami norm prawnych, co może nastąpić m.in. dzięki wykorzystaniu narzędzi komunikacji elektronicznej. Umiejętne włączenie tych ostatnich do praktyki funkcjonowania instytucji prawotwórczych wymaga jednak pogłębionej refleksji teoretycznej, zmian organizacyjnych oraz odpowiednich postaw adresatów prawa.

Pierwsza część rozważań poświęcona będzie koncepcji crowdsourcingu, który z socjologiczno-prawnego punktu widzenia może być traktowany jako symptom dokonującej się współcześnie zmiany paradygmatu sprawowania władzy publicznej, a zatem również funkcjonowania zinstytucjonalizowanych ośrodków decyzyjnych posiadających kompetencje do tworzenia regulacji prawnych. Następnie przedstawione zostaną etapy prawotwórczego procesu decyzyjnego ze wskazaniem tych działań, których jakość może, przynajmniej potencjalnie, zostać podniesiona dzięki wykorzystaniu tzw. mądrości tłumu. Ukazany zostanie też wpływ nowych metod partycypacyjnych na niektóre wymiary Modelu Pola Decyzyjnego Ustawodawcy, który zakłada m.in.: policentryczność współczesnych systemów prawnych (w związku z decentralizacją władzy państwowej, przejmowaniem kompetencji władz przez wyspecjalizowane agencje i/lub podmioty prywatne); jurydyzację życia społecznego; wzrost znaczenia prawa międzynarodowego (globalizacja); zmianę charakterystyki adresatów norm prawnych (ich upodmiotowienie i zróżnicowanie, rozwój aktywnych instytucji społeczeństwa obywatelskiego i mediów) oraz pojawienie się nowych form komunikacji z adresatami prawa [Pękala, 2016a: 271-291]. Wstępna analiza potencjału koncepcji crowdsourcingu i ewentualnych 
barier w jej implementacji jest niezbędna do rozpoczęcia krytycznej dyskusji nad kwestiami bardziej szczegółowymi, np. nad zasadnością konkretnych rozwiązań prawno-ustrojowych.

Wyżej zarysowany cel badawczy wymaga zastosowania podejścia interdyscyplinarnego, łączącego dorobek naukowych rozważań z zakresu takich dziedzin jak teoria organizacji, zarządzanie publiczne czy nauki polityczne z dorobkiem socjologii prawa i naukowej polityki prawa. Główną perspektywą badawczą będzie tu podejście decyzyjne, umożliwiające m.in. wyjaśnianie roli i znaczenia szerokiego katalogu czynników wpływających na organizację i skuteczność procesów decyzyjnych w rozwiązywaniu problemów społecznych [Supernat, 2003: 157-165; Pękala, 2016a: 75-93]. Podstawowe pojęcia podejścia decyzyjnego to: decydent (tu: prawotwórczy ośrodek decyzyjny), alternatywy decyzyjne, cechy poszczególnych alternatyw, etapy procesu decyzyjnego, uczestnicy (aktorzy społeczni) oraz strategie podejmowania i implementacji decyzji [Pękala, 2013: 187; Tyszka, 2010: 48-57; Groszyk, Korybski, 2008: 532-533]. Sama decyzja jest zaś definiowana jako proces związany ze świadomym wyborem określonego sposobu działania lub niedziałania dla osiągnięcia przez ośrodek decyzyjny określonego celu spośród możliwości wzajemnie wykluczających się oraz z realizacją wybranego wariantu [Ehrlich, 1994: 17, 41, 45, 47].

\section{Crowdsourcing a sprawowanie władzy publicznej}

Badacze crowdsourcingu traktują go jako specyficzną formę partycypacji podmiotów zewnętrznych (użytkowników, konsumentów itp.) w działaniach danej organizacji. Korzystanie z tzw. mądrości tłumu (mającego z natury charakter anonimowy i amorficzny) przeciwstawiane jest tradycyjnemu modelowi eksperckiemu. Crowdsourcing definiuje się jako „współpracę wielu osób przy tworzeniu pomysłów związanych ze wspólnym celem” [Radziszewska, 2013: 183] lub ,wykorzystywanie sieci społecznych do generowania i pozyskiwania treści” [Kinal, 2017: 117] czy też jako „dowolną aktywność (online lub offline) angażującą jakikolwiek rodzaj wiedzy, umiejętności lub zasoby finansowe szeroko pojętego tłumu (online lub offline) do wykonywania zadań (odpłatnie bądź bezpłatnie) określonych w zawartym zaproszeniu (online lub offline) przez osobę prywatną, organizację, instytucję non profit lub przedsiębiorstwo" [Kowalska, 2015: 145]. Pod uwagę brać można także: anonimowy lub jawny charakter projektu, ukierunkowanie go na diagnozę ogólnych kierunków działań (poziom strategiczny) lub rozwiązywanie konkretnych problemów (poziom operacyjny), zamknięty lub otwarty charakter zaproszenia, wewnętrzny lub zewnętrzny (względem ośrodka decyzyjnego) charakter grupy uczestników, wiążący lub niewiążący status uzyskanych wyników, oficjalną lub nieformalną formę. Na proces crowdsourcingu składają się fazy: przygotowawcza, inicjacji, generowania, oceny i wdrożenia [Kowalska, 2015: 158] lub: planowania, wdrożenia, utrzymania i analizy wyników [Slezkin, 2015: 29] czy też: publikacji zaproszenia, zaangażowania uczestników (przez ewentualne 
wyznaczenie im nagród), zbierania pomysłów, oceny rozwiązań przez społeczność (w formie komentowania lub głosowania), nagrodzenia najlepszego pomysłu i wdrożenia go [Radziszewska, 2013: 183]. Badania nad omawianym zjawiskiem prowadzić można w następujących kontekstach: ekonomicznym, informatycznym, społecznym oraz strukturalnym [Kowalska, 2015: 141]. Dla celu niniejszego artykułu zasadne będzie przyjęcie perspektywy społecznej, akcentującej fakt, że aktywowanie inteligencji zbiorowej ma funkcję integracyjną, a korzystanie z kapitału społecznego służy jednocześnie pomnażaniu go. Wykorzystanie crowdsourcingu w sferze publicznej daje wiele korzyści, takich jak: dostęp organizatora do ogromnych zasobów wiedzy zewnętrznej, sprzyjanie rozwiązaniom kreatywnym (możliwość wdrażania nowych pomysłów, wcześniej niebranych pod uwagę), niskie koszty, relatywnie krótki czas trwania konsultacji, usprawnienie komunikacji z otoczeniem, możliwość przewidywania przyszłych zachowań uczestników, wzrost jakości rozumiany jako lepsze dostosowanie usług publicznych do potrzeb adresatów, pozytywny efekt wizerunkowy, możliwość budowania społeczności wokół danego projektu (zagadnienia), przyczynia się również do aktywizacji wewnętrznych pracowników [Kowalska, 2015: 176-177; Radziszewska, 2013: 183: Wierżyński, 2015: 33-34].

W szerszej perspektywie rozwój nowych metod partycypacji publicznej może być traktowany jako symptom zmiany paradygmatu funkcjonowania instytucji władzy w społeczeństwie informacyjnym. Organy rządowe i samorządowe są bowiem obecnie traktowane raczej jako aktorzy funkcjonujący w ramach sieci, pozostający w stałym kontakcie z innymi podmiotami i raczej wysyłający do otoczenia impulsy w oczekiwaniu na reakcję niż stosujący twarde metody sterowania: „Sieciowa logika działania zaczyna funkcjonować również w obszarach, które dotąd były zarezerwowane dla pionowej organizacji i scentralizowanej biurokracji, to jest w obszarze państwowości" [Kulpa-Ogdowska, 2006: 139]. I tak: wśród założeń koncepcji Nowego Zarządzania Publicznego znajdują się m.in.: prywatyzacja, delegowanie uprawnień do wyspecjalizowanych agencji, wprowadzanie mechanizmów promujących konkurencję, decentralizacja instytucji władzy oraz umacnianie pozycji obywateli [Kjaer, 2009: 37-45]. Podobnie jedną z głównych zasad idei good governance jest stała współpraca ze społeczeństwem, polegająca m.in. na zastąieniu jednostronnych, odgórnych działań administracji publicznej dialogiem [Kisielewicz, 2009: 29]. Z tego powodu do najważniejszych metod i technik zarządzania publicznego zalicza się aktualnie np. zarządzanie sieciami organizacyjnymi, zarządzanie procesowe, zarządzanie partycypacyjne, zarządzanie innowacjami publicznymi oraz zarządzanie zaufaniem publicznym [Bogacz-Wojtanowska i in., 2016: 19]. Nowe metody partycypacji mają służyć nie tylko zwiększaniu efektywności zarządzania publicznego, ale też realizacji ideałów demokracji:

Jedną z najgłębszych intuicji liberalnej demokracji jest przekonanie, że ogólny rozwój naszej zdolności do gromadzenia i dzielenia informacji, a także do komunikowania się z innymi, wzmacnia demokratyczny sposób uprawiania polityki. Informacja i komunikacja, jak wierzymy, stanowią fundament demokracji, dlatego technologie, 
które poszerzają nasz dostęp do nich, muszą wnosić pozytywny wkład na rzecz demokracji i wzmocnienia praw [Barney, 2008: 155-156].

Decydenci publiczni muszą nauczyć się wykorzystywać ,potężne, względnie dostępne narzędzia organizacji, mobilizacji i działania dla politycznie aktywnych jednostek, grup oraz organizacji” i ,środki ulepszonej, regularnej obsługi, wertykalnej komunikacji pomiędzy obywatelami a urzędnikami i stanowiącymi prawo, umożliwiające poprawę w sferze reprezentacji obywatelskiej, reakcji na działania i dokładnego badania sprawy, a także zwiększenie odpowiedzialności” oraz „mechanizm umożliwiający bardziej bezpośrednie formy powszechnego uczestnictwa w demokratycznym podejmowaniu decyzji” [Barney, 2008: 158]. Warto tu wspomnieć również o koncepcji Web 2.0., ponieważ założenia tego kierunku dotyczą: upodmiotowienia obywateli, umasowienia procesów podejmowania decyzji oraz zmiany roli administracji rządowej [Rogowski, 2015: 50]. Niektórzy badacze przyjmują jednak wobec rozwoju tzw. nowych mediów postawy sceptyczne, wskazując, że tzw. mądrość tłumu niekiedy oznacza po prostu zanik profesjonalizmu, kultywowanie społecznego dowodu słuszności lub nadzór przez hiperwidzialność [Rogowski, 2015: 49].

Niezależnie od oceny społecznego znaczenia rozwoju nowych technologii trzeba przyznać, że cyfrowa społeczność już istnieje, a i bieżąca gra polityczna nazywana jest

[...] polityką 2.0, a więc taką, w której zadaniem państwa jest nie tyle narzucanie własnych treści, ile zapewnianie obywatelom możliwości wyrażania własnego zdania. Jest polityką zbiorowej inteligencji, której treści są wytwarzane wspólnie, pochodzą z wielu źródeł i wzajemnie się uzupełniają. Jest polityką nieformalnych obiegów, w której tracą znaczenie oficjalne, instytucjonalne kanały komunikowania się na linii: państwo - politycy - obywatele [Rogowski, 2015: 54].

Można w takim razie mówić również o ,administracji publicznej 2.0” oraz o ,systemie prawa 2.0”. Nietrudno dostrzec, że nowe technologie wkraczają też do sfery polityki publicznej i są wykorzystywane jako narzędzia realizacji różnorodnych celów przez instytucje wielu krajów (omówienia przykładów praktycznych znaleźć można chociażby w: Olszowski, 2016: 115-125; Szeląg, 2016: 165-170; Rogowski, 2015: 56-60). Dotyczy to także podejmowania decyzji prawotwórczych - znanym przypadkiem są prace nad projektem ustawy o ruchu pojazdów poza drogami publicznymi zainicjowane w 2013 roku w Finlandii [Szeląg, 2016]. Skoro praktyka zaczyna wyprzedzać teorię, to podjęcie badań naukowych w tym zakresie jest pilną koniecznością, niezależnie od tego, czy uznamy, że tworzenie prawa powinno odbywać się na podstawie modelu instrumentalnego, deliberatywnego czy pośredniego. Ewolucja paradygmatu sprawowania władzy publicznej została uwzględniona również i w założeniach Modelu Pola Decyzyjnego Ustawodawcy [Pękala, 2016a: 277-281], dlatego najlepszą formą ukazania potencjalnych zastosowań crowdsourcingu w polityce tworzenia prawa będzie przeanalizowanie poszczególnych jej etapów i wybranych kryteriów decyzyjnych. 


\section{Crowdsourcing a prawotwórczy proces decyzyjny}

Tworzenie prawa to:

[...] zespół uporządkowanych, następujących po sobie czynności (zarówno faktycznych, jak i konwencjonalnych), rozpoczynający się od podjęcia przez określony podmiot zamysłu, by dokonać określonych zmian w życiu społecznym przez ustanowienie norm prawnych i obejmujący w pełnym rozwinięciu przygotowanie oraz ustanowienie danego aktu prawotwórczego [Kustra, 1994: 16].

Prawotwórstwo jest więc procesem obejmującym ciąg decyzji „,kolejno na siebie się nakładających, chociaż nie ograniczającym się jedynie do procedury tworzenia prawa (legislacyjnej)" [Leszczyński, 2003: 9]. Wyróżnia się tu fazy: zapoczątkowania (programowania i ustalenia kalendarza, przygotowania i zredagowania tekstu), dokonania zmian (konsultacji, koordynacji, kontroli prawnej) oraz zakończenia (przygotowania do podjęcia decyzji, przyjęcia lub odrzucenia projektu) [Goetz, Zubek, 2005: 16-19]. Model Pola Decyzyjnego Ustawodawcy zakłada zaś fazy: identyfikacji (już dostrzeżonego lub prognozowanego) problemu decyzyjnego oraz kompleksowej diagnozy poszczególnych wymiarów pola decyzyjnego; wyznaczania wartości-celów, którym nowa regulacja będzie służyła (określenie podstawy aksjologicznej aktu prawnego); identyfikacji i oceny alternatyw decyzyjnych oraz dokonania wyboru; sformułowania tekstu aktu prawnego, uchwalenia go i promulgacji; realizacji decyzji, kontroli jej skuteczności oraz podjęcia ewentualnych działań korygujących [Pękala, 2016a: 339-351].

Dla przygotowania i oceny skuteczności każdego procesu decyzyjnego kluczowe znaczenie mają umiejętności ośrodka decyzyjnego w zakresie gromadzenia i przetwarzania zasobu informacji dotyczących danego problemu i związanej z nim hierarchii wartości [Ehrlich, 1994: 65]. Jedną z decyzji cząstkowych jest zaś określenie źródła tych informacji oraz kanałów ich pozyskiwania, przy czym procesy komunikacyjne pomiędzy prawotwórczym ośrodkiem decyzyjnym a adresatami decyzji normatywnych, zarówno na etapie przeddecyzyjnym, jak i na etapie wdrożenia i ewaluacji, powinny przebiegać dwukierunkowo [Ehrlich, 1994: 58]. W świetle wcześniejszych uwag na temat nowoczesnych metod sprawowania władzy publicznej nie budzi wątpliwości zasadność wykorzystywania różnorodnych narzędzi komunikacji elektronicznej w dialogu pomiędzy „e-ustawodawcą” a „e-adresatami prawa” [Pękala, 2016b: 189]. W odniesieniu do etapu przygotowawczego podkreśla się, że ,,aparat państwowy nie jest tu samodzielnym decydentem; obok niego rolę taką mogą pełnić partie polityczne oraz organizacje społeczne i grupy nacisku" [Leszczyński, 2003: 17], a dodać tu można również ,zwykłych” adresatów prawa, zarówno tych pozostających offline, jak i online. Autorzy Kodeksu Rzetelnych Praktyk Legislacyjnych wskazują, że konsultacje społeczne powinny odbywać się już w pierwszej fazie procesu decyzyjnego, jeszcze przed powstaniem projektu ustawy, aby „wszyscy partnerzy mieli zagwarantowany równy dostęp do informacji” [Bąk i in., 2007: 16]. Nic nie 
stoi na przeszkodzie, aby wstępne konsultacje treści nowego aktu prawotwórczego przeprowadzać z wykorzystaniem tzw. mądrości tłumu. Tego typu inicjatywę nazwać możemy crowdsourcingiem diagnostycznym, gdyż jego głównym celem będzie zebranie informacji na temat danego problemu decyzyjnego i opinii adresatów o możliwych sposobach jego rozwiązania.

Skoro jednym z głównych etapów procesu decyzyjnego, czasami determinującym skuteczność całego przedsięwzięcia, jest faza wdrożenia i kontroli skuteczności, to również i w przypadku implementacji nowych regulacji prawnych niezbędne jest wykorzystanie wszelkich dostępnych form komunikacji z adresatami prawa (w tym oczywiście narzędzi komunikacji elektronicznej) w celu gromadzenia informacji na temat ewentualnych przeszkód praktycznych lub trudności interpretacyjnych [Bąk i in., 2007: 17]. Korzystanie w tym zakresie z tzw. mądrości tłumu określić można mianem crowdsourcingu ewaluacyjnego, ponieważ służyć on będzie ocenie efektywności decyzji pierwotnej oraz konieczności podjęcia decyzji korygujących.

Model Pola Decyzyjnego Ustawodawcy uwzględnia następujące czynniki wpływające na skuteczność decyzji legislacyjnych: wymiar instrumentalny (dotyczący diagnozy problemu oraz określenia potencjalnych środków działania), wymiar aksjologiczny (dotyczący skali preferencyjnej wartości - celów ośrodka decyzyjnego oraz społecznych preferencji aksjologicznych związanych z danym problemem), wymiar gry o władzę (dotyczący czynników warunkujących polityczną wykonalność poszczególnych możliwości decyzyjnych), wymiar konfliktu społecznego (dotyczący sprzeczności interesów, z jakimi związany jest dany problem, i możliwościami ich rozwiązywania), wymiar dyskursywny (dotyczący mechanizmów uzgadniania racjonalności wewnętrznej prawotwórczego ośrodka decyzyjnego z racjonalnością adresatów oraz przełamywania ich oporu wobec zmian), wymiar społecznego systemu normatywnego (dotyczący granic regulacji normatywnej w ogóle oraz granic regulacji prawnej, a także relacji prawa z innymi rodzajami norm społecznych w kontekście danego problemu), wymiar ekonomiczny (dotyczący materialnych i społecznych kosztów wprowadzania nowych regulacji oraz zysków z tym związanych) oraz wymiar temporalny (dotyczący czasowych granic procesu decyzyjnego). Pełna analiza wpływu tzw. nowych mediów na każdą z wymienionych sfer wymagałaby odrębnego opracowania, dlatego poniżej zaprezentowane zostaną najważniejsze tezy w kontekście wymiarów: instrumentalnego, aksjologicznego i społecznego systemu normatywnego oraz konfliktu społecznego i dyskursywnego.

Diagnoza wymiaru instrumentalnego polega na zdefiniowaniu problemu oraz sformułowaniu katalogu prawnych środków oddziaływania możliwych do zastosowania przy jego rozwiązaniu. Chodzi o rzeczywiste (a nie oparte np. na mitach i stereotypach) czynniki krytyczne, które w danej sytuacji wymagają interwencji. $\mathrm{Na}$ etapie przygotowawczym określić należy m.in., jakie informacje są niezbędne do rozwiązania problemu oraz jaka jest jakość posiadanych danych. Kwestie te są ściśle powiązane z metadecyzjami prawotwórczego ośrodka decyzyjnego na temat podmiotów, które będą dopuszczone do uczestnictwa w debacie (model ekspercki lub model partycypacyjny) [Pękala, 2016a: 298-303]. Ocena możliwości przez 
wąskie grono specjalistów powinna być poprzedzana ogólną i szeroko zakrojoną refleksją nad wyznaczeniem celów nowej regulacji prawnej i środków jej implementacji [Majone, 2004: 96]. W poszukiwaniu wytycznych dotyczących sytuacji, w których zasadne byłoby wykorzystanie inteligencji zbiorowej, pomóc może odwołanie się do teorii organizacji, na której podstawie wyróżnia się np.: decyzje podejmowane dobrowolnie (w celu skorzystania z okazji, jaka się nadarza), decyzje problemowe (w celu zapobieżenia przewidywanym zjawiskom negatywnym) oraz kryzysowe [Supernat, 2003: 21-22]. Analizować można też: problemy o dobrze określonej strukturze (możliwe do skwantyfikowania, modelowania, pomiaru), o nieokreślonej strukturze (problemy do opisu jakościowego, słownego, które dotyczą zależności niedających się zmierzyć) oraz mieszane [Supernat, 2003: 23]. $\mathrm{Z}$ kolei ze względu na zakres wiedzy decydenta mówi się o problemach zamkniętych (selektywnych) - gdy decydent zna pełen katalog możliwych kierunków działania i ich konsekwencji, oraz otwartych (inwencyjnych) - gdy ta wiedza nie jest pełna, a rozwiązanie wymaga kreatywności [Pękala, 2013: 187; Supernat, 2003: 24]. Crowdsourcing diagnostyczny z pewnością może być pomocny w wypracowywaniu rozwiązań legislacyjnych w przypadku decyzji o charakterze dobrowolnym i problemowym, o nieokreślonej lub mieszanej strukturze oraz wymagających innowacyjności. Teoretycy organizacji wskazują również, że delegowanie zadań jest zasadne, jeśli przyczyni się do podniesienia skuteczności realizacji zadania, kształtowania postaw podwładnych (samorealizacji, poczucia uznania, odpowiedzialności, wzmocnienia motywacji i zaangażowania) lub rozwoju nowych umiejętności podwładnych (podnoszenia ich kompetencji merytorycznych) [Supernat, 2003: 37-38]. W kontekście niniejszych rozważań są to kolejne pola zastosowania crowdsourcingu diagnostycznego. Nie powinno się jednak delegować np. zadań wykraczających poza umiejętności i doświadczenie podwładnych, dotyczących kwestii poufnych, zastrzeżonych dla pracowników wyższego szczebla w hierarchii decyzyjnej, zagadnień z zakresu bezpieczeństwa oraz o charakterze strategicznym [Supernat, 2003: 39]. Katalog ten w dużej mierze jest zgodny z wyliczeniem sfer, w których nie powinno się stosować crowdsourcingu [Kasprzycki-Rosikoń, 2015: 39].

Diagnoza wymiaru aksjologicznego polega na identyfikacji wartości społecznych uzasadniających wprowadzenie nowych regulacji prawnych, co ma zasadnicze znaczenie z punktu widzenia ich finalnej skuteczności, a w szerszym zakresie jest związane $\mathrm{z}$ koniecznością dbania przez instytucje prawotwórcze o choćby minimalny poziom społecznej legitymizacji władzy politycznej oraz systemu prawnego. Nie ulega bowiem wątpliwości, że aksjologia prawa powinna przynajmniej do pewnego stopnia odzwierciedlać skale preferencyjne adresatów norm [Pękala, 2016a: 304-308]. Dotykamy tu problematyki objętej kolejnym wymiarem pola decyzyjnego ustawodawcy, czyli potencjalnych konfliktów projektowanej regulacji prawnej z obowiązującymi $\mathrm{w}$ danym społeczeństwie normami zwyczajowymi, moralnymi, religijnymi itp. [Pękala, 2016a: 324-329]. Nowe metody partycypacji mogą być, zarówno w kontekście aksjologicznym, jak i w kontekście interakcji prawa z innymi rodzajami norm społecznych, skutecznymi narzędziami określania społecznych uwarunkowań tworzenia i egzekwowania regulacji prawnych. 
Crowdsourcing diagnostyczny mógłby tu służyć do identyfikowania odczuwanego przez adresatów „zapotrzebowania” na nowe akty normatywne. Innymi słowy, można go traktować jako narzędzie do analizowania, czy w danej sferze stosunków społecznych istnieje odpowiednie społeczne przyzwolenie dla ingerencji instytucji państwowych posługujących się środkami prawnymi.

Diagnoza wymiaru konfliktu społecznego obejmuje określenie genezy i struktury oraz skutków sprzeczności związanych z daną sferą życia społecznego. Prawo tradycyjne bowiem odgrywa rolę ,,arbitra” w uzgadnianiu interesów różnych grup nacisku, a rola ta powinna być realizowana w sposób konstruktywny, a nie sprzyjający eskalacji wrogości. W tym zakresie do władzy prawotwórczej należy dbanie o skuteczną komunikację pomiędzy wszystkimi uczestnikami debaty [Pękala, 2016a: 314-317]. Ustawodawca jednak jest nie tylko organizatorem, ale i jednocześnie stroną dialogu społecznego, co związane jest z kolejnym - dyskursywnym - wymiarem pola decyzyjnego. Prawotwórczy ośrodek decyzyjny jest tu jednym z partnerów w komunikacji społecznej, starającym się argumentować, zyskiwać społeczne poparcie dla tych rozwiązań, które są korzystne z punktu widzenia interesu wspólnego, oraz przełamywać (lub przynajmniej minimalizować) opór adresatów przed wprowadzaniem nowych regulacji [Pękala, 2016a: 318-323]. Kluczowe znaczenie mają tu strategie komunikacyjne wykorzystywane przez legislatywę na poziomie racjonalnym, perswazyjnym i emocjonalnym. Samo uznanie określonego problemu społecznego za istotny oraz wysłuchanie i dowartościowanie poszczególnych grup społecznych służą budowie pozytywnego wizerunku władzy prawodawczej [Pękala, 2016b: 184]. Korzystanie z inteligencji zbiorowej $\mathrm{w}$ tym kontekście pomaga m.in. w określaniu panujących nastrojów społecznych, postaw różnych grup społecznych względem siebie oraz względem zamierzeń ustawodawcy. Za pomocą crowdsourcingu diagnostycznego zbierać można informacje niezbędne dla formułowania prognoz odnośnie do przyszłych reakcji adresatów na nowe regulacje. $Z$ kolei crowdsourcing ewaluacyjny wydaje się obiecującym narzędziem weryfikowania społecznych skutków aktów normatywnych.

\section{Zakończenie}

Z socjologiczno-prawnego punktu widzenia rozwój crowdsourcingu legislacyjnego stanowić mógłby przykład wprowadzania w życie postulatów idei prawa responsywnego, które (w przeciwieństwie do prawa represyjnego i autonomicznego) nie służy jedynie własnym, wewnętrznym celom, ale zmierza do realizacji celów ,uzgadnianych" w partnerskim dialogu z innymi podsystemami społecznymi [Winczorek, 2014: 360]. Korzystanie z tzw. mądrości tłumu jest zatem dobrą drogą do adaptowania się systemu prawnego do wymogów otoczenia, w szczególności przez uwzględnianie postulatów adresatów decyzji i wprowadzanie nowych regulacji w życie metodami „miękkimi” (soft law), a nie przepisami o bezwzględnej mocy wiążącej. Oczywiście, żaden projekt crowdsourcingowy nie 
zastąpi rzetelnej i szczerej debaty publicznej, ale może być dobrym sposobem na jej zainicjowanie. Korzystanie z tzw. mądrości tłumu może przyczynić się do odbudowania społecznego autorytetu prawa i być skutecznym sposobem na poprawę jakości regulacji, przy czym pamiętać należy o jego specyficznym kontekście (uwarunkowania prawne) oraz potencjalnie dużym zasięgu (tworzenie regulacji krajowych i międzynarodowych), a także o znacznym zakresie odpowiedzialności (wpływanie na stopień podmiotowości społecznej adresatów prawa, decydowanie o ich obowiązkach i uprawnieniach). Wskazane jest zatem zachowanie umiarkowanego sceptycyzmu wobec pytania o możliwość zrewolucjonizowania procesów tworzenia prawa przez omawianą koncepcję. Nie byłoby zasadne (ani możliwe) zastosowanie jej do wszystkich faz prawotwórstwa ani do wszystkich rodzajów regulacji prawnych. Poza tym warto pamiętać, że crowdsourcing w ogóle najczęściej traktowany jest jedynie jako metoda mająca uzupełniać, a nie zastępować główną działalność danej instytucji [Kowalska, 2015: 179]. Wymienione w niniejszym artykule potencjalne zastosowania tzw. mądrości tłumu mogą jednak stanowić podstawę dla dalszych analiz nad praktycznymi aspektami tworzenia regulacji prawnych.

Za podsumowanie rozważań niech posłuży tabela:

Tabela 1

Potencjalne zastosowania crowdsourcingu w odniesieniu do wybranych wymiarów pola decyzyjnego ustawodawcy

\begin{tabular}{|l|l|l|}
\hline \multicolumn{1}{|c|}{$\begin{array}{c}\text { Wymiary pola } \\
\text { decyzyjnego } \\
\text { ustawodawcy }\end{array}$} & Crowdsourcing diagnostyczny & \multicolumn{1}{c|}{ Crowdsourcing ewaluacyjny } \\
\hline $\begin{array}{l}\text { Wymiar } \\
\text { instrumentalny }\end{array}$ & $\begin{array}{l}\text { Wstępne rozpoznanie opinii adre- } \\
\text { satów prawa o danym problemie } \\
\text { decyzyjnym i zebranie pomysłów } \\
\text { na jego rozwiązanie }\end{array}$ & $\begin{array}{l}\text { Diagnoza praktycznych barier } \\
\text { w implementacji aktu normatyw- } \\
\text { nego }\end{array}$ \\
\hline Wymiar aksjologiczny & $\begin{array}{l}\text { Identyfikacja wartości społecz- } \\
\text { nych, którym powinna służyć } \\
\text { nowa regulacja }\end{array}$ & $\begin{array}{l}\text { Określenie zgodności podstawy } \\
\text { aksjologicznej regulacji z przeko- } \\
\text { naniami społecznymi }\end{array}$ \\
\hline $\begin{array}{l}\text { Wymiar społecznego } \\
\text { systemu normatywnego }\end{array}$ & $\begin{array}{l}\text { Rozpoznanie ryzyka konfliktu } \\
\text { nowych regulacji prawnych } \\
\text { z innymi rodzajami norm spo- } \\
\text { łecznych }\end{array}$ & $\begin{array}{l}\text { Określenie skutków interakcji } \\
\text { nowych norm prawnych z innymi } \\
\text { rodzajami norm społecznych }\end{array}$ \\
\hline $\begin{array}{l}\text { Wymiar konfliktu } \\
\text { społecznego }\end{array}$ & $\begin{array}{l}\text { Diagnoza postaw grup interesów } \\
\text { zainteresowanych projektowanym } \\
\text { aktem normatywnym }\end{array}$ & $\begin{array}{l}\text { Zbadanie wpływu nowej regulacji } \\
\text { na dynamikę danego konfliktu } \\
\text { społecznego }\end{array}$ \\
\hline Wymiar dyskursywny & $\begin{array}{l}\text { Formułowanie prognoz na temat } \\
\text { przyszłych reakcji adresatów } \\
\text { prawa na nową regulację }\end{array}$ & $\begin{array}{l}\text { Przełamywanie oporu adresatów } \\
\text { wobec przestrzegania nowych } \\
\text { norm prawnych }\end{array}$ \\
\hline
\end{tabular}

Źródło: opracowanie własne. 


\section{Bibliografia}

Barney D. (2008), Społeczeństwo sieci, tłum. M. Fronia, oprac. K. Nadana, Wydawnictwo Sic!, Warszawa.

Bąk M., Bednarz P., Kulawczuk P., Szcześniak A. (2007), Kodeks Rzetelnych Praktyk Legislacyjnych, Instytut Badań nad Demokracją i Przedsiębiorstwem Prywatnym, Warszawa.

Bogacz-Wojtanowska E., Jung-Konstanty S., Kożuch A., Kożuch B., Lewandowski M., Sułkowski Ł., Szczudlińska-Kanoś A., Sienkiewicz-Małyjurek K. (2016), Obszary zarzadzania publicznego, Instytut Spraw Publicznych UJ, Kraków.

Ehrlich S. (1994), Dynamika norm. Podstawowe zagadnienia wiażacych wzorów zachowania, wyd. 2, Wydawnictwa Szkolne i Pedagogiczne, Warszawa.

Goetz K.H., Zubek R. (2005), Stanowienie prawa w Polsce. Reguly legislacyjne a jakość ustawodawstwa, Ernst \& Young S.A., Poland, Warszawa.

Groszyk H., Korybski A. (2008), Podejście decyzyjne w prawoznawstwie (zarys problematyki) [w:] W. Witkowski (red.), W kręgu historii i wspótczesności polskiego prawa. Księga jubileuszowa dedykowana profesorowi Arturowi Korobowiczowi (s. 531-546), Wydawnictwo Uniwersytetu Marii Curie-Skłodowskiej, Lublin.

Kasprzycki-Rosikoń J. (2015), Negatywne przejawy crowdsourcingu [w:] F. Milewski (red.), Ttum jako źródło wiedzy i kapitału (s. 36-42), Polska Agencja Rozwoju Przedsiębiorczości, Warszawa, https://www.parp.gov.pl/images/PARP_publications/pdf/2015_tlum_ jako_zrodlo_wiedzy_i_kapitalu_v_3_0ps.pdf. [dostęp: 10.2017].

Kinal J. (2017), Crowdsourcing - próba deskrypcji zjawiska, „UR Journal of Humanities and Social Sciences”, 1(2), 116-125. doi:10.15584/johass.2017.1.7

Kisielewicz J. (2009), Istota i zasady good governance, „Administracja: Teoria, Dydaktyka, Praktyka", 2(15), 7-32.

Kjaer A.M. (2009), Rzqdzenie, tłum. M. Dera, Wydawnictwo Sic!, Warszawa.

Kowalska M. (2015), Crowdsourcing internetowy. Pozytywny wymiar partycypacji społecznej. Konteksty - Istota - Uwarunkowania, Wydawnictwo Stowarzyszenia Bibliotekarzy Polskich, Warszawa.

Kulpa-Ogdowska A. (2006), Właczeni i wytaczeni z globalnej sieci. Społeczne konsekwencje rozwoju nowoczesnych technologii i konsumeryzmu, „Nierówności Społeczne a Wzrost Gospodarczy", 8, 137-154.

Kustra E. (1994), Polityczne problemy tworzenia prawa, Wydawnictwo Uniwersytetu Mikołaja Kopernika, Toruń.

Leszczyński L. (2003), Podejmowanie decyzji prawnych. Tworzenie i stosowanie prawa, Wyższa Szkoła Zarządzania i Administracji, Zamość.

Majone G. (2004), Dowody, argumenty i perswazja w procesie politycznym, tłum. D. Sielski, Wydawnictwo Naukowe Scholar, Warszawa.

Olszowski R. (2016), Elektroniczna republika. Udziat obywateli w życiu publicznym z wykorzystaniem narzędzi ICT [w:] K. Oświecimski, A. Pohl, M. Lakomy (red.), NetoDEMOkracja. Web 2.0 w sferze publicznej (s. 111-130), Akademia Ignatianum, Wydawnictwo WAM, Kraków.

Pękala M. (2013), Podejście decyzyjne w prawoznawstwie [w:] A. Kociołek-Pęksa, M. Stępień (red.), Leksykon socjologii prawa (s. 186-191), C.H. Beck, Warszawa. 
Pękala M. (2016a), Pole decyzyjne ustawodawcy, Akademia Ignatianum, Wydawnictwo WAM, Kraków.

Pękala M. (2016b), Ustawodawca jako organizator i uczestnik prawotwórczego procesu decyzyjnego [w:] K. Oświecimski, A. Pohl, M. Lakomy (red.), NetoDEMOkracja Web 2.0 w sferze publicznej (s. 171-192), Akademia Ignatianum, Wydawnictwo WAM, Kraków.

Radziszewska A. (2013), Crowdsourcing jako forma wykorzystania innowacyjności wirtualnych społeczności, „Współczesne Zarządzanie”, 2, 180-189.

Rogowski Ł. (2015), Państwo - polityka - internet. Rola nowych mediów w funkcjonowaniu współczesnych systemów politycznych [w:] M. Baranowski (red.), Funkcjonalne i dysfunkcyjne aspekty społeczeństwa sieciowego (s. 47-67), Człowiek i Społeczeństwo, 40, Wydawnictwo Naukowe Uniwersytetu im. Adama Mickiewicza, Poznań.

Slezkin M. (2015), Jak skutecznie zarzqdzać procesem w projektach crowdsourcingowych? [w:] F. Milewski (red.), Ttum jako źródło wiedzy i kapitału (s. 20-29), Polska Agencja Rozwoju Przedsiębiorczości, Warszawa, https://www.parp.gov.pl/images/PARP_publications/pdf/2015_tlum_jako_zrodlo_wiedzy_i_kapitalu_v_3_0ps.pdf [dostęp: 15.10.2017].

Supernat J. (2003), Techniki decyzyjne i organizatorskie, wyd. 2. popr. i uzup., Kolonia Limited, Wrocław.

Szeląg I. (2016), Crowdsourcing prawa. Zastosowanie nowoczesnych technologii w tradycyjnych instytucjach demokracji bezpośredniej [w:] K. Oświecimski, A. Pohl, M. Lakomy (red.), NetoDEMOkracja. Web 2.0 w sferze publicznej (s. 155-172), Akademia Ignatianum, Wydawnictwo WAM, Kraków.

Tyszka T. (2010), Decyzje. Perspektywa psychologiczna i ekonomiczna, Wydawnictwo Naukowe Scholar, Warszawa.

Wierżyński W. (2015), Wady i zalety stosowania crowdsourcingu [w:] F. Milewski (red.), Tłum jako źródło wiedzy i kapitału (s. 30-35), Polska Agencja Rozwoju Przedsiębiorczości, Warszawa, https:/www.parp.gov.pl/images/PARP_publications/pdf/2015_tlum _ jako_zrodlo_wiedzy_i_kapitalu_v_3_0ps.pdf [dostęp: 15.10.2017].

Winczorek J. (2014), Prawo responsywne [w:] A. Kojder, Z. Cywiński (red.), Socjologia prawa. Główne problemy i postacie (s. 359-363), Wydawnictwa Uniwersytetu Warszawskiego, Warszawa.

Zirk-Sadowski M. (2013), Polityka prawa [w:] A. Kociołek-Pęksa, M. Stępień (red.), Leksykon socjologii prawa (s. 191-201), C.H. Beck, Warszawa. 